\title{
ESTIMATION OF DIETARY HABITS AND PHYSICAL ACTIVITY AMONG YOUNG POPULATION IN VOJVODINA: BMI-FOR-AGE APPROACH
}

\author{
Zita I. Šereš ${ }^{1}$, Ferenc E. Kiš ${ }^{2}$, Dragana M. Šoronja Simović ${ }^{1}$, Peter Raspor ${ }^{3}$, Marijana Z. Djordjević ${ }^{1}$, \\ Miljana Z. Djordjević ${ }^{1}$, Sonja Smole Možina ${ }^{3}$, Nikola R. Maravić ${ }^{1}$, Jana J. Zahorec ${ }^{1}$ \\ ${ }^{1}$ University of Novi Sad, Faculty of Technology, Department of Carbohydrate Food Engineering, \\ 21000 Novi Sad, Bulevar cara Lazara 1, Serbia \\ ${ }^{2}$ University of Novi Sad, Faculty of Technology, Department of General Education Subjects, 21000 \\ Novi Sad, Bulevar cara Lazara 1, Serbia \\ ${ }^{3}$ University of Ljubljana, Biotechnical Faculty, Department of Food Science and Technology, 1000 \\ Ljubljana, Jamnikarjeva 101, Slovenia
}

${ }^{*}$ Corresponding author:

Phone: +381214853685

E-mail address: miljanadj@tf.uns.ac.rs

\begin{abstract}
Healthy diet and development of proper dietary habits in adolescence combined with sufficient physical activity are recognized as the key factors of a long-term health. This study was conducted to gain an insight into the dietary habits, the frequency of meal intake and physical activity of the young population by applying a survey. Surveyed participants were Hungarian nationality students who attended elementary and high schools in the province of Vojvodina, Serbia. The total number of participants was 525 (42.5\% males and $57.5 \%$ females) most of which were from the rural area. To address the nutritional status and risk for overweight among the young population, body mass index (BMI) of the participants was determined. The majority of participants had normal range nutritional status $(70.48 \%)$ followed by overweight $(19.81 \%)$ and obese $(7.62 \%)$. Overweight and obese nutritional statuses were more common among male participants. Increasing number of participants with overweight nutritional status was noticed in the $7^{\text {th }}$ grade of elementary school $(25.81 \%)$. Insufficient physical activity and irregularities in meals intake were also noticed within the studied population which is an indicator of potential obesity development in adulthood.
\end{abstract}

Key words: young population, diet quality, meal frequency, body mass index, physical activity

\section{INTRODUCTION}

According to the concept presented by the World Health Organization (WHO, 2016a), a healthy diet should include high intake of fruits, vegetables, and whole grains, coupled with low intake of saturated fats, salt, and refined carbohydrates. The right amount of energy and nutrients intake also reduces the risk of the long-term health problems particularly obesity, cardiovascular diseases and type 2 diabetes (Rossiter et al., 2012). Decisions regarding what to eat, when to eat and how much to eat represent our dietary habits. Understanding dietary habits is crucial since our food choices have significance for individual health and thus the general health of the entire community.

Proper nutrition is essential for young children optimal growth and development. It is established that cognitive functioning and academic performance of children are connected to diet quality as well as break- 
fast consumption (Hoyland et al., 2009; Florence et al., 2008). Dietary habits established during childhood and adolescence are usually maintained later in life (Singer et al., 1995). However, concern about young population dietary habits is rising since high levels of fast food consumption, low intake of fruits and vegetables, and breakfast skipping seems to be common among young population (Larson et al., 2012; Niemeier et al., 2006). In case those aforementioned unfavourable dietary habits are not corrected in adolescence, they tend to be carried further into adulthood and may lead to long-term health implications.

One of the most important factors which affect young population dietary habits is family environment established by the household economic situation and related living conditions, place of residence, as well as parental education (Powell et al., 2010). Parents commonly shape children's dietary habits which should be later complemented with the proper education provided in schools. With the beginning of school education factors such as the school environment and peers also gain greater impact on dietary habits, considering a prolonged time of being outdoors due to school attendance (Krusinska et al., 2017). In addition, direct positive influence on school children dietary habits can be implemented through policies regarding diversity and price of foods available in schools. However, a potentially negative influence in relation to dietary habits could be gained indirectly through peer's body image perception (Stevenson et al., 2007). Furthermore, dietary habits and the diversity of consumed food are greatly dependent on socioeconomic status since low economic status might alter children's current and long-term dietary habits (Krusinska et al., 2017). Not all factors affecting dietary habits are changeable but, environmental and food-related experiences are, and these are proved to be crucial for the children's dietary habits development (Birch, 1999).

Another emerging problem related to young population diet is time and frequency of meal intake and meal skipping. Common habits among the young po- pulation are skipping or having an inappropriate or insufficient breakfast and replacing dinner with snacks. An outcome of such habits could be low nutritional diet quality caused by inappropriate nutrient intake and an increased risk for overweight and obesity (Rodrigues et al., 2017). Additionally, factors such as high-density energy intake, sedentary lifestyle and lack of physical activity also have an impact on obesity development among the young population. More than double increase in obesity rate occurred since 1980 worldwide implying an emerging problem (Meşe et al., 2017). To assess the individual's nutritional status, regarding obesity, body mass index (BMI) is used. According to the $\mathrm{WHO}$ a 4 class classification considering $\mathrm{BMI}$ is presented: underweight $\left(B M l<18.5 \mathrm{~kg} / \mathrm{m}^{2}\right.$ ), normal range (BMI 19-24.99 $\mathrm{kg} / \mathrm{m}^{2}$ ), overweight (BMl $\geq 25$ $\left.\mathrm{kg} / \mathrm{m}^{2}\right)$ and obese $\left(\mathrm{BMl} \geq 30 \mathrm{~kg} / \mathrm{m}^{2}\right)$ valid for adults of both genders (WHO, 2016b). In order to estimate children's nutritional status WHO developed special Growth Charts for school-aged children and adolescents and introduced BMl cut-offs in respect to BMI for adults (WHO, 2007). The share of obese $\left(B M l \geq 30 \mathrm{~kg} / \mathrm{m}^{2}\right)$ in the adult population in Serbia was $21.50 \%$ for both genders according to the data reported by the WHO (2016c). Considering corresponding shares in the surrounding countries, excluding Bosnia and Herzegovina, Serbia is a country with the lowest prevalence of obesity and occupies $31^{\text {st }}$ place in Europe. Obesity is on third place among risk factors $(24.8 \%)$ for the development of cardiovascular diseases, which are the leading cause of mortality in Serbia (54\%) (WHO, 2014). The leading risk factor for the development of diabetes in Serbia is overweight $(57.5 \%)$, while second and third place occupy physical inactivity (41.4\%) and obesity (21.1\%) (WHO, 2016d).

To prevent the emergence of health implications in adulthood, tracking the dietary habits among the young population is crucial as well as tracking of other factors (environmental factors, socioeconomic status, food availability, food-related experiences) which affect these habits. The objective of the present study was to esti- 
mate and compare basic dietary habits, the frequency of meal intake and physical activity of elementary and high school students considering their BMI.

\section{MATERIALS AND METHODS}

\section{Study population}

Survey was conducted in elementary and high schools in the province of Vojvodina, Serbia among Hungarian nationality students. Participants were students attending $5^{\text {th }}$ and $7^{\text {th }}$ grade of elementary school and $3^{\text {rd }}$ grade of high school with age ranging from 11 to 18 . The total number of surveyed participants was 525 of which 223 were males $(42.5 \%)$ and 302 were females $(57.5 \%)$. The majority of the participants were from rural area $(80 \%)$. Basic characteristics of the studied population are presented in Table 1. The participation in the survey was anonymous and on a voluntary basis. Information about study's aim and collected data handling were envisaged to participants before completing the questionnaire.

\section{Survey characteristics}

A self-designed questionnaire was developped in order to collect information on dietary habits, the frequency of meal intake and physical activity of the participants. One section of the questionnaire included demographic data (gender and age) along with social and cultural data focused on degree course and place of residence. In the second section, participants completed the questionnaire by marking the offered responses on their dietary habits and physical activity practice.

\section{Data analysis}

The answers provided by the survey were coded and collected in a database using Microsoft Excel 2010. Results were processed using the pivot tables in the Microsoft Excel 2010 and expressed as the percentage of participants based on BMI. For the graphical presentation of the survey results, Statistica 13.3 (TIBCO Software Inc., USA) was used.

\section{RESULTS AND DISCUSSION}

Survey was conducted among Hungarian nationality students during 2017/2018 school year in elementary and high schools in the province of Vojvodina, Serbia. High school students were among the majority of the surveyed population (38.9\%), followed by the participants from $7^{\text {th }}$ $(35.4 \%)$ and $5^{\text {th }}(25.7 \%)$ grade of elementary school. With respect to gender, the number of female participants was slightly higher compared to male participants (Tab. 1). Nutritional status of the studied population based on BMI-for-age considering gender and education level is presented in Tables 2 and 3, respectively.

Table 1.

Basic characteristics of the studied population

\begin{tabular}{|c|c|c|c|c|c|c|}
\hline \multirow{2}{*}{ Education level } & \multicolumn{2}{|c|}{ Males } & \multicolumn{2}{|c|}{ Females } & \multicolumn{2}{|c|}{ Total } \\
\hline & $\mathbf{n}$ & $\%$ & $\mathbf{n}$ & $\%$ & $\mathbf{n}$ & $\%$ \\
\hline $\begin{array}{l}\text { Elementary school } 5^{\text {th }} \\
\text { grade }\end{array}$ & 66 & 48.89 & 69 & 51.11 & 135 & 100 \\
\hline $\begin{array}{l}\text { Elementary school } 7^{\text {th }} \\
\text { grade }\end{array}$ & 86 & 46.24 & 100 & 53.76 & 186 & 100 \\
\hline High school $3^{\text {rd }}$ grade & 71 & 34.80 & 133 & 65.20 & 204 & 100 \\
\hline Total & 223 & 100 & 302 & 100 & 525 & \\
\hline
\end{tabular}

Table 2.

Distribution of males and females $(n)$ in the studied population according to the BMI-for-age

\begin{tabular}{lcccccc}
\hline \multirow{2}{*}{ BMI classification } & \multicolumn{2}{c}{ Males } & \multicolumn{2}{c}{ Females } & \multicolumn{2}{c}{ Total } \\
\cline { 2 - 7 } & $\mathbf{n}$ & $\mathbf{n}$ & $\mathbf{n}$ & $\mathbf{\%}$ & $\mathbf{n}$ & $\mathbf{\%}$ \\
\hline Underweight & 2 & 0.90 & 9 & 2.98 & 11 & 2.10 \\
Normal range & 142 & 63.68 & 228 & 75.50 & 370 & 70.48 \\
Overweight & 53 & 23.77 & 51 & 16.89 & 104 & 19.81 \\
Obese & 26 & 11.66 & 14 & 4.64 & 40 & 7.62 \\
\hline Total & 223 & 100 & 302 & 100 & 525 & 100 \\
\hline
\end{tabular}


Table 3.

Distribution of education levels in the studied population according to the BMI-for-age

\begin{tabular}{|c|c|c|c|c|c|c|c|c|c|c|}
\hline \multirow{3}{*}{ Education level } & \multicolumn{10}{|c|}{ BMI classification } \\
\hline & \multicolumn{2}{|c|}{ Underweight } & \multicolumn{2}{|c|}{ Normal range } & \multicolumn{2}{|c|}{ Overweight } & \multicolumn{2}{|c|}{ Obese } & \multicolumn{2}{|c|}{ Total } \\
\hline & $\mathbf{n}$ & $\%$ & $\mathbf{n}$ & $\%$ & $\mathbf{n}$ & $\%$ & $\mathbf{n}$ & $\%$ & $\mathbf{n}$ & $\%$ \\
\hline Elementary school $5^{\text {th }}$ grade & 3 & 2.22 & 94 & 69.63 & 22 & 16.30 & 16 & 11.85 & 135 & 100 \\
\hline Elementary school $7^{\text {th }}$ grade & 5 & 2.69 & 117 & 63.90 & 48 & 25.81 & 16 & 8.60 & 186 & 100 \\
\hline High school $3^{\text {rd }}$ grade & 3 & 1.47 & 159 & 77.94 & 34 & 16.67 & 8 & 3.92 & 204 & 100 \\
\hline Total & 11 & 2.10 & 370 & 70.48 & 104 & 19.81 & 40 & 7.62 & 525 & 100 \\
\hline
\end{tabular}

Participants with normal range nutritional status were the most numerous $(\sim 70 \%$, Tab. 2 and 3) followed by participants with overweight nutritional status $(\sim 20 \%$, Tab. 2 and 3) regardless of gender and education level. Underweight and obese nutritional status in the studied population was recorded in a lesser extent with a share of $2.1 \%$ and $7.62 \%$, respectively (Tab. 2 and 3). Considering gender, there were more overweight and obese males $(23.77 \%$ and $11.66 \%$, respectively) compared to the females $(16.89 \%$ and $4.64 \%$, respectively) (Tab. 2). Furthermore, the number of females with normal range nutritional status was about $11 \%$ higher compared to males (Tab. 2). Underweight nutritional status among females was $2.98 \%$, while for males was $0.9 \%$.

Considering education level, the number of overweight participants was $10 \%$ higher in $7^{\text {th }}$ grade of elementary school compared to the $5^{\text {th }}$ grade and $3^{\text {rd }}$ grade of high school (Tab. 3). Increase in the number of overweight participants in $7^{\text {th }}$ grade of elementary school $(25.81 \%)$ consequently reflected on decrease in the number of participants with normal range nutritional status $(63.90 \%$, Tab. 3$)$. The share of participants with normal range nutritional status within the $5^{\text {th }}$ grade of elementary school was around $70 \%$ while for $3^{\text {rd }}$ grade of high school was the highest, $77.94 \%$. Distribution of participants with underweight nutritional status was approximately uniform across the examined education levels (Tab. 3). A small group of participants with underweight nutritional status was present in the studied population $(2.10 \%)$ which is reflected by their wider share regarding calculations based on their number, and hence these results were considered irrelevant.

In terms of physical activity, the results showed that $59.43 \%$ of participants were engaged in some physical activity which is in agreement with findings of SimovskaJarevska et al. (2012). 40\% of participants were physically inactive which could potentially forecast a sedentary lifestyle with all its consequences in adulthood (Ács et al., 2011). When addressing the frequency of physical activity, only $18.64 \%$ of participants were physically active on daily basis, whereas $47.91 \%$ and $33.44 \%$ of participants were active $3-4$ and 1-2 times per week, respectively. In Figure 1 are presented responses obtained for leisure-time physical activity practice among participants in relation to BMI-forage. A higher share of participants with normal range nutritional status $(60.81 \%)$ affirmed that they were physically active compared to participants with obese nutritional status (55\%).

The opposite results were observed for the lack of physical activity, $38.38 \%$ and $45 \%$ of participants with normal range and obese nutritionnal status, respectively (Fig. 1). Obtained results showed that participants with effective physical activity had lower BMI similarly to the previous findings re-ported by the Breitenbach et al. (2016) and Saris et al. (2003).

As regard to the meal skipping and meal frequency, it is determined that $11.05 \%$ of all participants do not have breakfast at all, while snack $(8.76 \%)$, lunch $(6.29 \%)$, and dinner $(2.86 \%)$ are omitted in a lower percentage. Breakfast was also the most skipped meal $(47.83 \%)$ among participants. These results are consistent with the previous study of Meşe et al., (2017) conducted in Turkey where the breakfast skipping share was $39.2 \%$.

A similar study conducted in Bosnia and Herzegovina reveal that only $25 \%$ of participants have regular breakfast (Lošić and Čačić Kenjerić, 2015). 


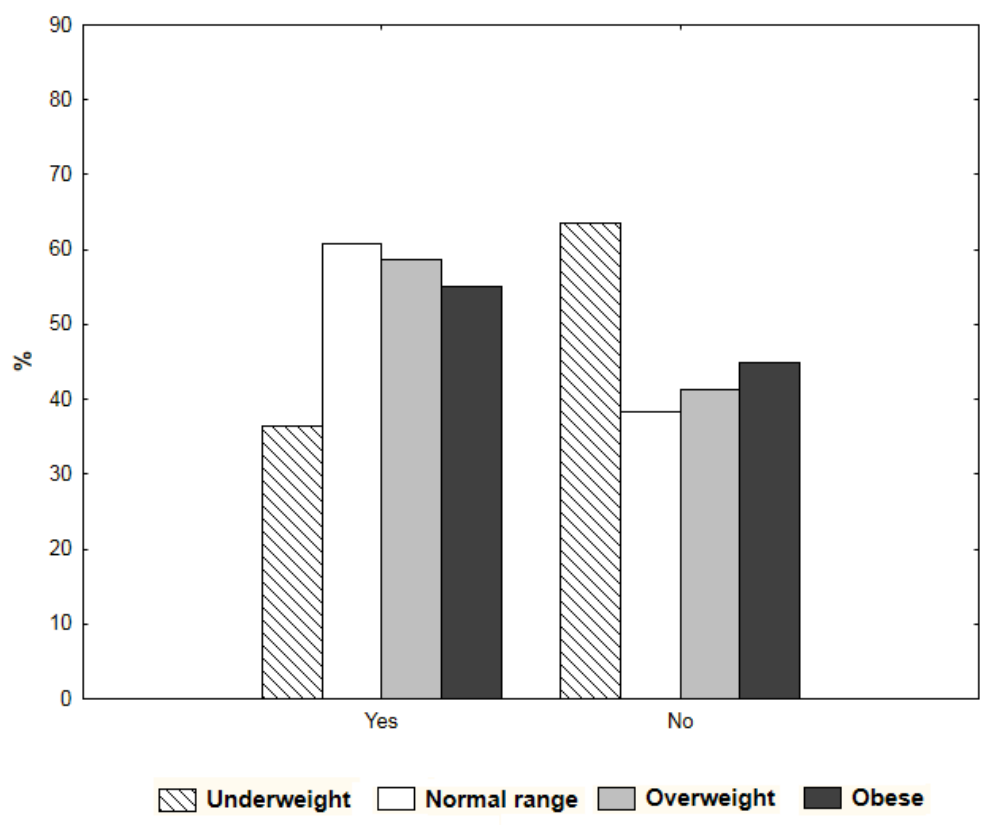

Figure 1. Regular physical activity practice among the studied population according to the BMI-for-age

Making a habit of breakfast skipping in childhood tend to be carried into adulthood and is correlated with higher values of fasting insulin, higher BMI, higher total cholesterol, and low-density lipoprotein cholesterol concentrations (Smith et al., 2010). The regular number of main meals per week had $66.48 \%$ of participants whereas the number of snacks between meals was lower than recommended. $33.52 \%$ of participants stated that they have one snack in a day which is in accordance with reported results from similar study (Meşe et al., 2017). Discouraging fact is that only $0.19 \%$ of participants consumed two snacks on daily basis considering that consumption of five meals per day is important for school children growth and cognitive function development. Additionally, main meals skipping on daily basis influences the metabolism of carbohydrates and lipids, and is related with a reduced thermogenic effect of foods, hence affecting long-term weight gain (Farshchi et al., 2015).

Figure 2 illustrates the number of weekly meals in the studied population considering classification according to BMI-forage. With respect to breakfast con-sumption, $41.08 \%$ of participants with nor-mal range nutritional status and $50 \%$ of parti- cipants with obese nutritional status followed the pattern of regular breakfast consumption on daily basis (Fig. 2). In the study of Taljić (2015) conducted in Canton of Sarajevo share of participants with normal rage nutritional status was two times higher $(81 \%)$, whereas much lower percentage of participants with overweight $(10.1 \%)$ and obese nutritional status (5.3\%) consumed breakfast on daily basis compared to presented study. Nevertheless, $10.27 \%$ of participants with normal range nutritional status do not have breakfast at all, likewise $17.5 \%$ of participants with obese nutritional status (Fig. 2 ). Furthermore, the habit of having breakfast two or five times per week in approximate share $(\sim 11 \%)$ was observed within participants with normal range and overweight nutritional statuses (Fig. 2). Nevertheless, the share of participants with obese nutritional status regarding mentioned frequencies of meal intake differed, $2.50 \%$ for two times and $15 \%$ for five times a week. When addressing the lunch consumption, comparing participants with normal range and obese nutritional status, large differences were not observed since $81-85 \%$ stated that consume lunch on daily basis (Fig. 2). Less than $1 \%$ of all participants, regardless of nutritional status, stated that they do not have lunch. 

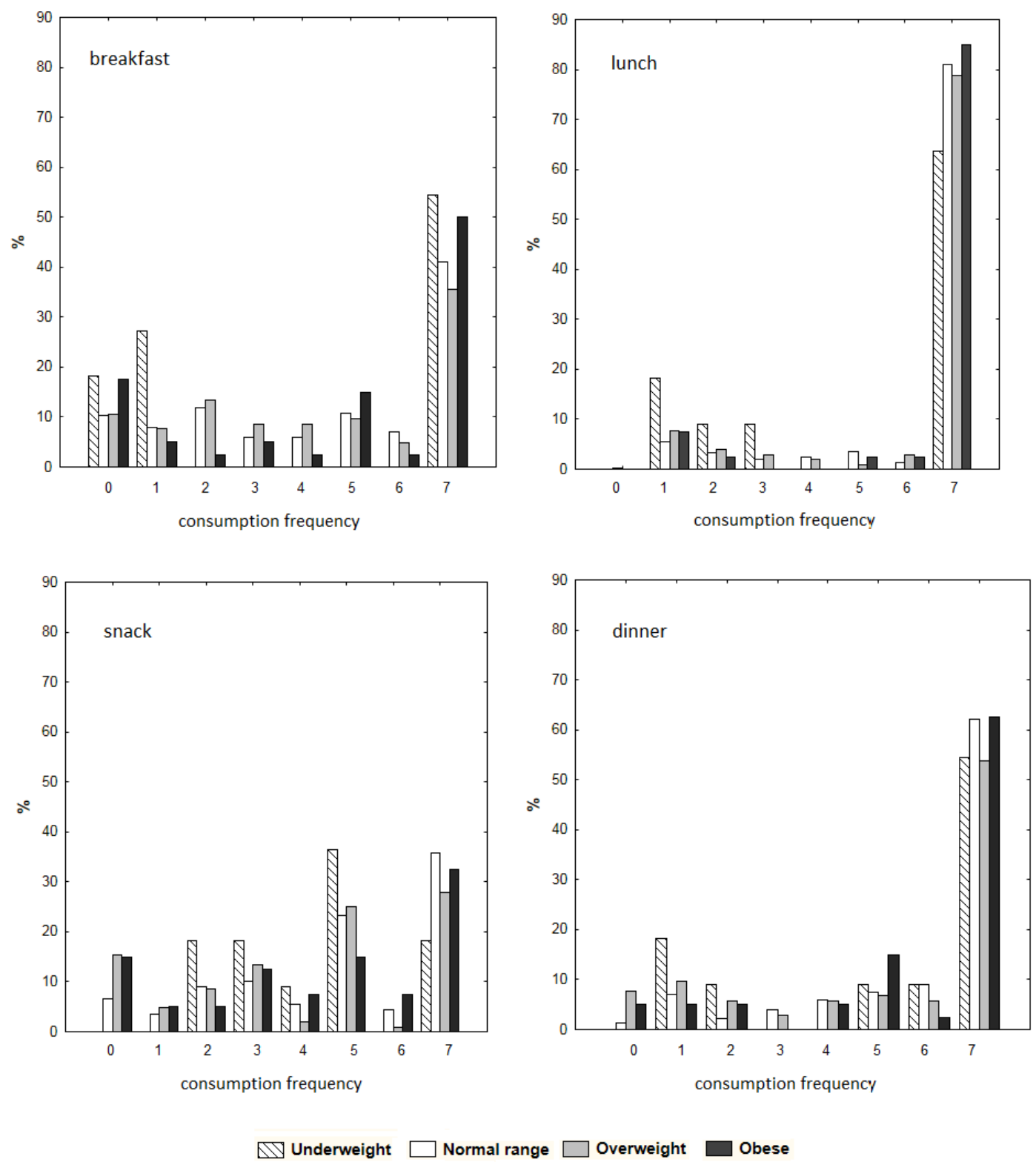

Figure 2. Number of weekly meals in the studied population according to the BMI-for-age

Still, $5.41 \%$ of participants with normal range nutritional status and $7.50 \%$ of participants with obese nutritional status have lunch once a week (Fig. 2). In contrast to our findings, Meşe et al. (2017) reported that the most skipped meal in Turkey among students besides breakfast $(39.2 \%)$ was lunch $(39.7 \%)$. With respect to snack consumption, $35.68 \%$ of participants with normal range nutritional status and $32.50 \%$ of participants with obese nutritional status have one snack on daily basis (Fig. 2). In contrast, $15-15.38 \%$ of participants with overweight and obese nutritional statuses confirmed that they do not have snack at all which was approximately two times higher compared to participants with normal range nutritional status. Habit of having snack five times per week was noticed for $23.24 \%$ of participants with normal range and $15 \%$ of participants with obese nutritional status (Fig. 2). As regard to dinner consumption, $62.16 \%$ of participants with normal range nutritional status and $62.50 \%$ of participants with obese nutritional status followed the pattern of regular dinner consumption on daily basis (Fig. 2). Similarly to snacks, 
a higher percentage of participants with obese nutritional status (5\%) stated that they do not have dinner when compared to participants with normal range nutritional status $(1.35 \%)$. Nevertheless, the habit of having dinner once per week was more noticeable among participants with normal range nutritional status $(7.03 \%)$ compared to participants with obese nutritional status $(5 \%)$. On the other hand, dinner consumption five times per week was most frequent among participants with obese nutritional status (15\%) (Fig. 2). To over-come irregularities in meal intake, adopting proper eating habits in early childhood is essential. Furthermore, maintenance of the adopted habits should be a priority regardless of other activities.

The obtained results concerning the frequency of various foods consumption according to the BMI-for-age are summarized in Table 4. The participants were asked to respond on intake frequency of basic foodstuff from the food pyramid and foodstuff considered as unhealthy (pizza and carbonated juices). It was noticed that meat was consumed usually 2-4 times a week among all participants regardless of nutritional status (Tab. 4). Participants with normal range nutritional status were the most numerous regarding the mentioned frequency of meat consumption $(57.57 \%)$ followed by overweight $(52.88 \%)$, obese $(52.50 \%)$ and underweight $(45.45 \%)$ participants. These findings are in agreement with results obtained in the study of Lošić and Čačić Kenjerić (2015) conducted among young population in Bosnia and Herzegovina where $35.3 \%$ of studied population affirmed that consumes meat 2-3 times a week. Compared to participants with normal range nutritional status, overweight nutritional status participants consumed meat in a higher extent on daily basis $(22.22 \%)$ but also more often exclude meat from the diet $(10.42 \%$, Tab. 4). Bread and bakery products were consumed most frequently on daily basis regardless of nutritional status (Tab. 4). This was expected since bakery products, especially bread, are traditionally consumed in large quantities in the Western Balkan region which was confirmed through previous studies (Šereš et al., 2017a; Šereš et al., 2017b; Simovska-Jarevska et al.,
2012). Nevertheless, a decrease in daily basis consumption of bread and bakery products from $90.91 \%$ to $55 \%$ was observed among nutritional status classes from underweight to obese. Furthermore, it was noticed that participants with the overweight and obese nutritional statuses more often omit or even exclude bread from the diet compared to participants with underweight and normal range nutritional status (Tab. 4). It is assumed that participants with corresponding nutritional status are more attentive to weight control and the prevailing opinion is that bread consumption contributes to gain in body weight which is the main reason for avoidance.

The highest share of fruits consumption on daily basis $(\geq 54.55 \%)$ was reported by participants from all nutritional status classes (Tab. 4). Corresponding frequency of fruit consumption was also reported among adolescents in the study of Lošić and Čačić Kenjerić (2015) and male adolescents in the study of Taljić (2015). Participants with overweight nutritional status were the most numerous regarding daily fruit consumption $(68.75 \%)$ while the share of participants with other nutritional statuses was in the range of $54.55 \%-57.30 \%$ (Tab. 4). The reported frequency of pizza consumption for all participants regardless of nutritional status was 1-2 times a month (Tab. 4).

Participants who reported pizza consumption at corresponding frequency in the highest share were those with normal range nutritional status $(52.16 \%)$. The same share for participants with overweight, obese and underweight statuses was 4-16\% lower (Tab. 4). Compared to participants with normal range nutritional status, participants with obese nutritional status consumed pizza in a higher extent on daily basis $(10 \%)$.

However, an interesting observation was that the highest share of participants with overweight nutritional status (10.42\%) confirmed that pizza was not included in their diet, followed by participants with obese nutritional status $(10 \%$, Tab. 4). The frequency of carbonated juices consumption differed for different nutritional statuses (Tab. 4). 
Table 4.

Relation between participants' BMI-for-age and consumption of various foods

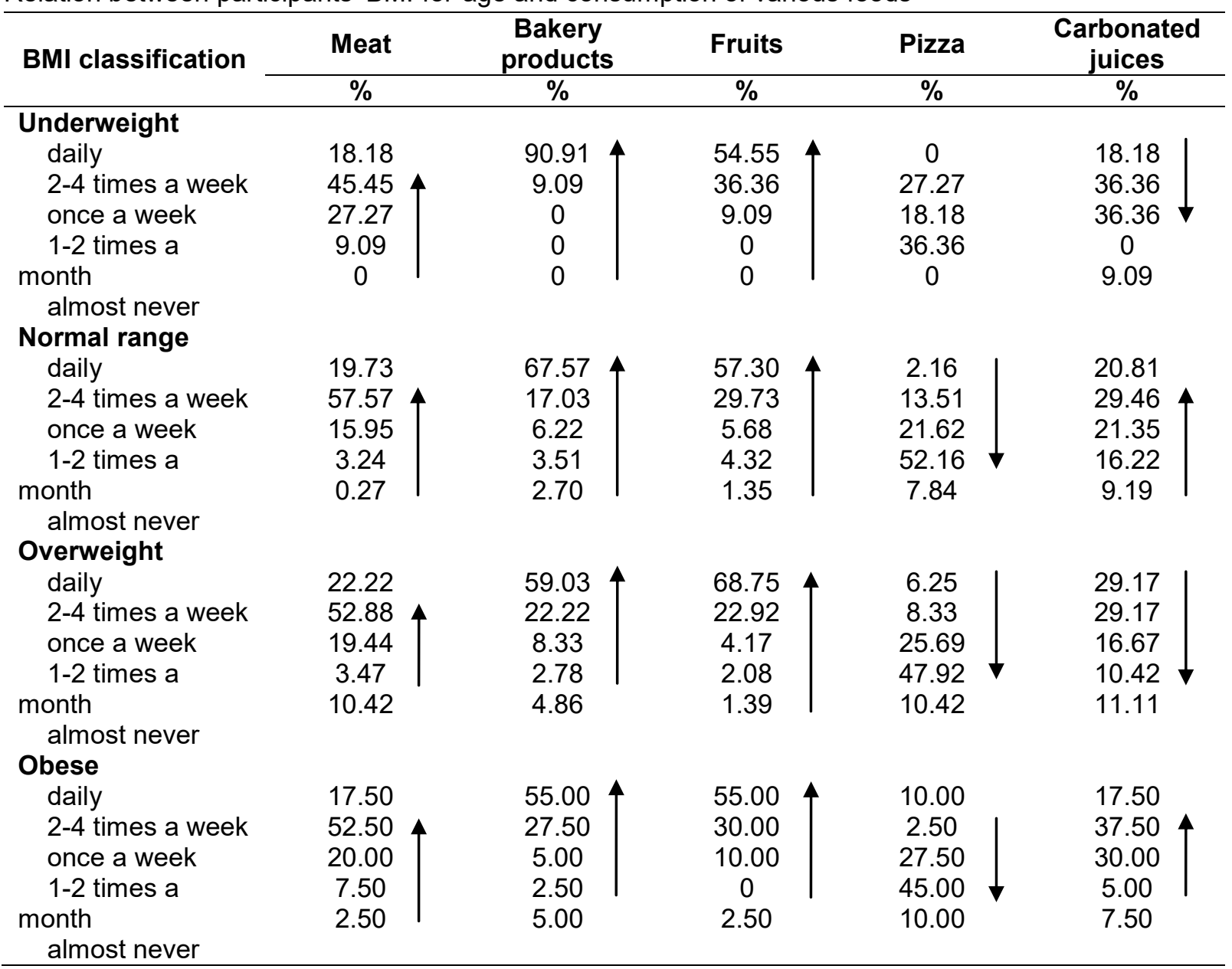

The highest intake of carbonated juices on daily basis was observed among participants with overweight nutritional status (29.17\%, Tab. 4). However, the highest share of participants with normal range nutritional status $(29.46 \%)$ stated that they drink carbonated juices 2-4 times a week. Similarly to pizza, participants with overweight nutritional status $(11.11 \%)$ confirmed carbonated juices exclusion from diet in higher extent compared to participants with normal range nutritional status $(9.19 \%)$.

\section{CONCLUSIONS}

This study aimed to give an insight on elementary and high school students' dietary habits and physical activity in relation to BMI-for-age. Although the most of participants fall within normal range nutritional status, sedentary lifestyle, physical inactivity, and habits of main meals skipping are emerging among the studied young population. Confirmation of this observation relies on increasing number of obese participants among $5^{\text {th }}$ grade elementary school students as well as increased number of overweight participants among $7^{\text {th }}$ grade elementary school students.

High risk for obesity development in adolescence could forecast long-term health implications with consequences in adulthood, and hence alter the general health of the entire community. In order to completely understand development and changes in dietary habits, a complex influence of many factors needs to be considered and wider population subjected to a survey.

\section{ACKNOWLEDGEMENTS}

This study is supported by Project of the Provincial Secretariat of Vojvodina for Higher Education and Scientific Research (Project no. 142-451-2637/2017). 


\section{REFERENCES}

1. Ács, P., Hécz, R., Paár, D., Stocker, M. (2011). The fitness value. Economic burdens of physical inactivity in Hungary. Journal of Economic Literature, 58, 689-708.

2. Birch, L.L. (1999). Development of food preferences. Annual Review of Nutrition, 19 (1), 41-62.

3. Breitenbach, Z., Raposa, B., Szabó, Z., Polyák, É., Szács, Z., Kubányi, J., Figler, M. (2016). Examination of Hungarian college students' eating habits, physical activity and body composition. European Journal of Integrative Medicine, 8S, 13-17,

DOI:10.1016/j.eujim.2016.11.007.

4. Farshchi, H.R., Taylor, M.A., Macdonald, I.A. (2015). Beneficial metabolic effects of regular meal frequency on dietary thermogenesis, insulin sensitivity, and fasting lipid profiles in healthy obese women. American Journal of Clinical Nutrition, 81, 16-24, DOI:10.1093/ajcn/81.1.16.

5. Florence, M.D., Asbridge, M., Veugelers, P.J. (2008). Diet quality and academic performance. Journal of School Health, 78, 209-215, DOI:10.1111/j.1746-1561.2008.00288.x

6. Hoyland, A., Dye, L., Lawton, C.L. (2009). A systematic review of the effect of breakfast on the cognitive performance of children and adolescents. Nutrition Research Reviews, 22, 220243, DOI:10.1017/S0954422409990175.

7. Krusinska, B., Kowalkowska, J., Wadolowska, L., Wuenstel, J.W., Slowinska M.A., Niedzwiedzka E. (2017). Fibre-related dietary patterns: socioeconomic barriers to adequate fibre intake in polish adolescents. Nutrients, 9, 590, DOI:10.3390/nu9060590

8. Larson, N., Laska, M.N., Story, M., NeumarkSztainer, D. (2012). Predictors of fruit and vegetable intake in young adulthood. Journal of the Academy of Nutrition and Dietetics, 112, 1216-1222, DOI:10.1016/j.jand.2012.03.035.

9. Lošić, D., Čačić Kenjerić, D. (2015). Does knowledge influences our diet? Dietary habits of adolescents enrolled in general profile and catering school programme. Food in Health and Disease, 4 (2), 98-104.

10. Meşe, C., Koca Özer, B., Sağir, M., Sağir, S., Özdemir A., Önal, S., Acar, S. (2017). Evaluation of dietary patterns and health status of young adults from Turkey: University students from urban and rural provinces. Advances in Nutrition and Food Science, 2 (1), 1-8.

11. Niemeier, H.M., Raynor, H.A., Lloyd-Richardson, E.E., Rogers, M.L., Wing, R.R. (2006). Fast food consumption and breakfast skipping: Predictors of weight gain from adolescence to adulthood in a nationally representative sample. Journal of Adolescent Health, 39, 842-849, DOI:10.1016/j.jadohealth.2006.07.001.

12. Powell, L.M., Han, E., Chaloupka, F.J. (2010). Economic contextual factors, food consumption, and obesity among U.S. adolescents. The Journal of Nutrition, 140, 1175-1180, DOI:10.3945/jn.109.111526.
13. Rodrigues, P.R.M., Luiz, R.R., Monteiro, L.S., Ferreira, M.G., Goncalves-Silva, R.M.V., Pereira, R.A. (2017). Adolescents' unhealthy eating habits are associated with meal skipping. Nutrition, 42, 114-120, DOI:10.1016/j.nut.2017.03.011.

14. Rossiter, M.D., Evers, S.E., Pender, A.C. (2012). Adolescents' diet do not comply with 2007 Canada's food guide recommendations. Appetite, 59, 668-672, DOI:10.1016/j.appet.2012.07.018

15. Saris, W.H., Blair, S.N., van Baak, M.A., Eaton, S.B., Davies, P.S., Di Pietro, L. (2003). How much physical activity is enough to prevent unhealthy weight gain? Outcome of the IASO 1 st stock conference and consensus statement. Obesity Reviews, 4, 101-114, DOI:10.1046/j.1467-789X.2003.00101.x.

16. Simovska-Jarevska, V., Damjanovski, D., Pavlova, V., Martinovski, S., Vidin, M. (2012): Evaluation of dietary habits and physical activity level monitoring as basis for a new health promotion strategy in Republic of Macedonia. Procedia-Social and Behavioral Sciences, 44, 370-374, DOI:10.1016/j.sbspro.2012.05.041.

17. Singer, M.R., Moore, L.L., Garrahie, E.J., Ellison, R.C. (1995). The tracking of nutrient intake in young children: The Framingham children's study. American Journal of Public Health, 85, 1673-1677.

18. Smith, K.J., Gall, S.L., McNaughton, S.A., Blizzard, L., Dwyer, T., Venn, A.J. (2010). Skipping breakfast: longitudinal associations with cardiometabolic risk factors in the childhood determinants of adult health study. American Journal of Clinical Nutrition; 92, 1316-25, DOI:10.3945/ajcn.2010.30101.

19. STATISTICA (Data Analysis Software System) (2018). v.13.3., TIBCO Software, Inc., USA

20. Stevenson, C., Doherty, G., Barnett, J., Muldoon, O.T., Trew, K. (2007). Adolescents' views of food and eating: Identifying barriers to healthy eating. Journal of Adolescence, 30, 417-434,

DOI:10.1016/j.adolescence.2006.04.005.

21. Šereš, Z., Šoronja Simović, D., Grujičić, M., Kiš, F., Djordjević, M., Šimurina, O., Šaranović, Ž., Maravić, N. (2017b). Dietary fibres and bread: attitudes, beliefs and knowledge among young population. Food and Feed Research, 44 (2), 143-149, DOI:10.5937/FFR1702143S.

22. Šereš, Z., Šoronja Simović, D., Grujičić, M., Maravić, N., Kiš, F., Dokić, Lj., Nikolić, I., Đorđević, M., Šaranović, Ž. (2017a). Bread as indicator of age-changing dietary habits among young people. Food in Health and Disease, 6 (2), 78-84.

23. Taljić I. (2015). Eating habits of male adoles cents in relation to BMl-for-age and place of residence. Food in Health and Disease, 4 (2), 85-92.

24. WHO (2007). Growth reference 5-19 years. (Retrieved May 15, 2018 from http://www.who.int/growthref/who2007 bmi for age/en/).

25. WHO (2014). Noncommunicable Diseases (NCD) Country Profiles (Retrieved June 7, 2018 
from

(http://www.who.int/nmh/countries/srb en.pdf).

26. WHO (2016a). Fact sheet on healthy diet (No 394). Geneva, Switzerland (Retrieved Oct. 20, 2017 from (http://www.who.int/mediacentre/factsheets/fs3 94/en/).

27. WHO (2016b). BMI classification (Retrieved May 15, 2018 from

(http://apps.who.int/bmi/index.jsp?introPage=int ro 3.html).
28. WHO (2016c). Prevalence of obesity among adults, $B M I \geq 30$, age-standardized estimates by country (Retrieved June 2, 2018 from (http://apps.who.int/gho/data/view.main.CTRY2 450A? lang=en).

29. WHO (2016d). Diabetes country profiles (Retrieved June 7, 2018 from http://www.who.int/diabetes/countryprofiles/srb en.pdf)

\section{НАВИКЕ У ИСХРАНИ И ФИЗИЧКА АКТИВНОСТ ОМЛАДИНЕ У ВОЈВОДИНИ У ЗАВИСНОСТИ ОД ИНДЕКСА ТЕЛЕСНЕ МАСЕ}

Зита И. Шереш ${ }^{1}$, Ференц Е. Киш ${ }^{2}$, Драгана М. Шороња Симовић${ }^{1}$, Петер Распор ${ }^{3}$, Маријана 3. Ђорђевић ${ }^{1}$, Миљана 3.Ђорђевић ${ }^{* 1}$, Соња Смоле Можина ${ }^{3}$, Никола Р. Маравић ${ }^{1}$, Јана Ј. Захорец ${ }^{1}$

${ }^{1}$ Универзитет у Новом Саду, Технолошки фракултет, Катедра за инжењерство угљенохидратне хране, 21000 Нови Сад, Булевар цара Лазара бр. 1, Србија

${ }^{2}$ Универзитет у Новом Саду, Технолошки фракултет, Катедра за опште инжењерске дисциплине, 21000 Нови Сад, Булевар цара Лазара бр. 1, Србија

${ }^{3}$ Универзитет у Љубљани, Биотехнички факултет, Катедра за прехрамбену технологију, 1000 Љубљана, Јамникарјева бр. 101, Словенија

Сажетак: Здрава исхрана и развијање здравих навика у исхрани у периоду адолесценције заједно са одговарајућом фризичком ативношћу препознати су као кључни фактори за добро дугорочно здравље. Ово истраживање спроведено је у виду анкетног упитника са циљем да се прикупе информације о навикама у исхрани, учесталости конзумирања оброка и упражњавању фризичке активности међу омладином. У истраживању су учествовали ученици основних и средњих школа у Војводини (Србија) мађарске националности. Истраживањем је обухваћено 525 испитаника (42,5\% дечака и 57,5\% девојчица) већином настањених у руралним подручјима. Индекс телесне масе испитаника одређен је како би се проценио нутритивни статус и ризик од појаве прекомерне телесне тежине међу омладином. Већина испитаника имала је нормални нутритивни статус (70,48\%), док је број оних са прекомерном телесном тежином $(19,81 \%)$ и гојазних $(7,62 \%)$ био мањи. Више гојазних и оних са прекомерном телесном тежином било је међу дечацима. Повећање броја деце са прекомерном телесном тежином забележено је у седмом разреду основне школе $(25,81 \%)$. У популацији обухваћеној истраживањем такође је забележена недовољна физичка активност и нередовност у конзумирању оброка што је индикатор за потенцијални развој гојазности у зрелом добу.

Кључне речи: омладина, квалитет исхране, учесталост оброка, индекс телесне масе, фозичка активност

Received: 22 May 2018

Received in revised form: 15 June 2018

Accepted: 20 June 2018 